\title{
Flexural Properties of Resin-modified "Hybrid" Glass-ionomers in Comparison with Conventional Acid-base Glass-ionomers
}

\author{
Yasuko MOMOI, Kunitsugu HIROSAKI, Atsushi KOHNO and John F. McCABE ${ }^{1}$ \\ Department of Operative Dentistry, School of Dental Medicine, Tsurumi University, \\ 2-1-3, Tsurumi, Tsurumi-ku, Yokohama, 230, Japan. \\ ${ }^{1}$ Dental Materials Science Unit, The Dental School, Framlington Place, \\ Newcastle upon Tyne, NE2 4BW, UK.
}

Received April 5, 1995/Accepted October 27, 1995

\begin{abstract}
The mechanical properties of resin-modified "hybrid" glass-ionomers, for both restorative and liner/base applications, were assessed by a flexural test and compared with those of conventional acid-base glassionomers. Flexural strength, flexural modulus, and the modulus of resilience were determined 30 minutes after mixing, and at 24 hours and 3 months after aging in distilled water at $37^{\circ} \mathrm{C}$. With a microscope and SEM observations, a comparison of marginal breakdown was made between a resin-modified and a conventional glass-ionomer restoration in bovine cavities, after cyclic loading with steel balls. It was found that resin-modified glass-ionomers were stronger, more flexible, and more resilient than conventional acid-base glass-ionomers. This was in accord with the finding that less marginal breakdown and surface deterioration occurred in a resin-modified glass-ionomer than in a conventional analogue. For some materials the flexural properties progressively improved between 24 hours and 3 months, while others showed no improvement or even deteriorated.
\end{abstract}

Key words: Glass-ionomers, Flexural strength, Resilience

\section{INTRODUCTION}

Mathis and Ferracane ${ }^{1)}$ first produced a glass-ionomer/resin-composite hybrid material by simply mixing the liquid from a commercial glass-ionomer cement restorative with an experimental resin to form a light-curable system. The first resin-modified glass-ionomer product on the market consisted of a reactive fluoro-alumino-silicate glass and poly (alkenoic acid) containing pendant methacrylate groups. The setting mechanism of this cement was well documented by Mitra et $a l_{.}{ }^{2}$. This and other similar products undergo setting both by an acid-base reaction and a light-initiated cross-linking of the methacrylate groups.

The resin-modified glass-ionomers may overcome one of the main disadvantages of the conventional glass-ionomers, namely the sensitivity to moisture contamination during setting, while nonetheless preserving such advantageous properties as bonding to enamel and dentin ${ }^{3)}$ and the release of fluoride ions ${ }^{4)}$. With regard to mechanical properties, brittleness is a dominant feature in conventional acid-base glass-ionomers. For this reason these products are unsuitable for use in major stress bearing sites. However, in resin-modified hybrid materials the resin component may impart a greater toughness than could be achieved 
with a conventional cement ${ }^{1,5}$. The most salient mechanical property of cements that has been measured generally is compressive and diametral compressive strength; therefore, glass-ionomers have traditionally been evaluated using compression testing specified of the water-based cement in the ISO Specification (ISO 9917, 1986). Theoretically compression testing can be adopted to the strength measurement for the materials of fully brittle. Conventional acid-base glass-ionomers are basically brittle materials, so when force is exerted on them they tend to fracture abruptly with minimal deformation. However, resinmodified glass-ionomer is not as brittle, hence some plastic flow may be expected. Nicholson et $a l .{ }^{5)}$ demonstrated elastic characteristics shown in resin-modified glass-ionomers and found that specimens stored in water showed considerable deformation when loaded, becoming barrel-shaped prior to fracture. Furthermore, from a technical point of view a standard -compressive-strength specimen cannot be prepared from a single mix of resin-modified materials, because light can cure the material with a small depth. Anstice et al. ${ }^{6}$ ) reported that samples of glass-ionomer produced by the build-up of layers gave significantly lower compressive strength values than those produced in one piece. The researchers concluded that compressive strength is unsatisfactory as a measure of strength for resin-modified glass -ionomer material. To determine the strength of this material, the flexural test was considered the most suitable, with measurement of clearly defined parameters ${ }^{7)}$. In a recent review on the strength of resin-modified glass ionomer materials ${ }^{8)}$ there is some confusion regarding the reported flexural properties of this new cement ${ }^{9-11)}$. This may arise from the fact that very few studies of this cement involving the flexural test have been carried out. In this study, therefore, the mechanical properties of resin modified cements and conventional cements have been compared using a flexural test.

The purpose of this study was to test our hypothesis that addition of resins to glassionomers would improve their flexural properties, consequently when resin-modified material is restored in a cavity its improved properties would result in less marginal breakdown and surface deterioration after exposure to mechanical stress.

\section{MATERIALS AND METHODS}

\section{Flexural test}

The glass-ionomers used in this study are listed in Table 1. Four resin-modified glassionomers were compared with four acid-base conventional glass-ionomers. Materials were handled according to the manufacturers' instructions. After the mixing of powder and liquid each material was loaded into a polypropylene mold $(2 \times 2 \times 25 \mathrm{~mm})$ positioned over a polyester matrix strip on a glass slab. The surface of the material was covered with another matrix strip and pressure was gently applied through application of a second glass slab. For conventional glass-ionomers, the matrix strips were removed 10 minutes after mixing and the exposed surfaces of the specimens were varnished*, after which they were stored at $37^{\circ} \mathrm{C}$ and $100 \%$ relative humidity for 20 minutes. Resin-modified glass-ionomers were loaded into the mold in the same manner. Light activation was performed by exposure to a light activation 
unit** through the matrix strip for 120 seconds ( $60 \mathrm{~s}$ from each side). After light exposure, the matrix strips were removed and the exposed surfaces of the specimens were varnished. Specimens were then stored for 20 minutes at $37^{\circ} \mathrm{C}$ and $100 \%$ relative humidity, after which they were removed from the molds. The first flexural test was carried out at 30 minutes after mixing. Specimens to be tested at 24 hours and 3 months were transferred in distilled water at $37^{\circ} \mathrm{C}$ for storage. Ten specimens of each of the 8 materials were tested at each testing time. Tests were done using a universal testing machine ${ }^{\#}$ according to the 3-point loading method outlined in ISO 4049 (1988).

Flexural strength (S), in $\mathrm{MPa}$, was calculated from the equation $\mathrm{S}=3 \mathrm{FL} / 2 \mathrm{bh}^{2}$, where $\mathrm{F}$ is the maximum force $(\mathrm{N})$ exerted on the specimen, $\mathrm{L}$ is the distance $(\mathrm{mm})$ between the supports, $b$ is the width $(\mathrm{mm})$ and $h$ is the height $(\mathrm{mm})$ of the specimen. The flexural modulus (E), in $\mathrm{GPa}$, was calculated from the equation $\mathrm{E}=\mathrm{F}_{1} \mathrm{~L}^{3} / 4 \mathrm{bh}^{3} \mathrm{~d}$, where $\mathrm{F}_{1}$ is the force $(\mathrm{N})$ at a convenient point on the straight line portion of the force/deflection trace and $\mathrm{d}$ is the deflection $(\mathrm{mm})$ at force $\mathrm{F}_{1}$. The proportional limit $(\mathrm{P})$ in $\mathrm{MPa}$ was calculated from $\mathrm{P}=3 \mathrm{~F}_{2}$ $\mathrm{L} / 2 \mathrm{bh}^{2}$, where $\mathrm{F}_{2}$ was the maximum force $(\mathrm{N})$ on the straight line portion of the force/ deflection trace. The modulus of resilience $(R)$, in $\mathrm{MJ} / \mathrm{m}^{3}$, was then calculated using the equation $\mathrm{R}=\mathrm{P}^{2} / 2 \mathrm{E}$.

The resulting data were analyzed by two-way ANOVA for the variables of material and storage time. Post-hoc comparison of means were done by Duncan's multiple range test.

\section{Observation of marginal breakdown}

Two restorative glass-ionomers, FIIR and FIIC, were examined. A cylindrical cavity (4 mm in diameter, $2 \mathrm{~mm}$ in depth) was prepared centrally on the labial enamel surface of a bovine tooth, after which the cavity was conditioned with $10 \%$ polyacrylic acid for 20 seconds. The material was then slightly overfilled into the cavity and covered with a matrix strip. For FIIC the matrix strip was removed 5 minutes after the end of the cement mixing and varnish

Table 1 Glass-ionomers tested in this study

\begin{tabular}{|c|c|c|}
\hline Material & Code & Type \\
\hline \multicolumn{3}{|l|}{ For restorative } \\
\hline Fuji Ionomer Type II LC ${ }^{1}$ & FIIR & Resin-modified \\
\hline Fuji Ionomer Type II $^{1}$ & FIIC & Conventional \\
\hline Photac-Fil APLICAP 2 & PFR & Resin-modified \\
\hline Ketac-Fil APLICAP ${ }^{2}$ & $\mathrm{KFC}$ & Conventional \\
\hline \multicolumn{3}{|l|}{ For liner/base } \\
\hline Fuji Lining LC $^{1}$ & FLR & Resin-modified \\
\hline Lining Cement ${ }^{1}$ & FLC & Conventional \\
\hline Photac-Bond APLICAP 2 & PBR & Resin-modified \\
\hline Ketac-Bond APLICAP ${ }^{2}$ & $\mathrm{KBC}$ & Conventional \\
\hline
\end{tabular}

* * LUXOR 4000, ICI, Cheshire, UK

\# AUTOGRAPH-AG-500A, Shimadzu Co., Kyoto, Japan 
was applied. For FIIR the surface of the material was exposed to light for 40 seconds and a strip was removed following a varnish application. Sample teeth were then kept in a container at $100 \%$ relative humidity and $37^{\circ} \mathrm{C}$ for 20 minutes before being transferred to distilled water at $37^{\circ} \mathrm{C}$. After one week the restoration was finished and polished by successive use of a carbide finishing bur and a flexible abrasive point. A device used for mechanical cyclic loading was detailed in a previous paper ${ }^{12)}$. It consisted of two main parts, a plastic cylinder and a motor drive. Two sample teeth were fixed inside the lid of a cylinder and $300 \mathrm{~g}$ of small steel balls $(3.1 \mathrm{~mm}$ in diameter) were placed in the cylinder. The cylinder was then reciprocated at $100 \mathrm{cycles} / \mathrm{min}$ for 20,000 cycles so that the surfaces of the sample teeth were repeatedly impacted against the steel balls, during which the cylinder room was kept wet by distilled water maintained at $37^{\circ} \mathrm{C}$. After 20,000 cycles of loading the sample surface was observed through a binocular microscope and an impression was taken to fabricate a replica model for SEM ${ }^{\#}$ observation.

\section{RESULTS}

Table 2 shows the flexural strength values at 30 minutes and after 24 hours and 3 months of water storage. In the glass-ionomers used for restorative applications, resin-modified products were significantly stronger than the acid-base conventional materials except for the case of PFR and KFC at 30 minutes. In the glass ionomers used for liner/base applications flexural strength of FLR was greater than that of FLC, however, the strength was not greater in PBR compared to KBC. FIIR, FIIC, FLR, and FLC showed a significant increase in

Table 2 Flexural strength (MPa), mean (S.D.)

\begin{tabular}{|c|c|c|c|}
\hline & $30 \mathrm{~min}$ & $24 \mathrm{~h}$ & $3 \mathrm{~m}$ \\
\hline FIIR & $38.3(5.1)$ & $26.7(4.4)$ & $82.4(8.9)$ \\
\hline FIIC & $8.9(2.1) \mathrm{A}$ & $10.9(1.4)$ & $32.6(8.5) \mathrm{B}$ \\
\hline PFR & 10.5 (1.6) AB & $63.9(6.3)$ & $44.6(3.9)$ \\
\hline $\mathrm{KFC}$ & $14.1(1.4) \mathrm{AB}$ & $20.7(2.0) \mathrm{A}$ & $22.7(6.2) \mathrm{A}$ \\
\hline FLR & $17.7(3.0) \mathrm{B}$ & $18.1(4.3) \mathrm{A}$ & $54.4(9.1)$ \\
\hline FLC & $4.2(0.8)$ & $3.4(1.0)$ & $9.9(5.3)$ \\
\hline PBR & $12.3(1.0) \mathrm{AB}$ & $36.8(4.6) \mathrm{B}$ & $24.4(6.3) \mathrm{A}$ \\
\hline $\mathrm{KBC}$ & $26.7(2.0)$ & $35.5(5.6) \mathrm{B}$ & $34.1(4.8) \mathrm{B}$ \\
\hline
\end{tabular}

Means with the same letters are not significantly different $(\mathrm{p}>0.05)$.

Horizontal bars connect values which are not significantly different. 
flexural strength after 3 months of water storage, while PFR, KFC, PBR, and KBC showed no change or a decrease in strength during 3 months of water storage.

Flexural modulus values are given in Table 3. For the glass ionomers used for restorative applications, modulus values were significantly greater in conventional acid-base products than for resin-modified materials. In products used for liner/base applications modulus values of $\mathrm{KBC}$ and FLC at 3 months were significantly greater than those of PBR and FLR respectively, but there was no difference between FLR and FLC at 30 minutes and 24 hours. FIIR, FIIC, FLR, FLC, and KFC significantly increased in the modulus values following 3 months of water storage. For PFR, PBR, and $\mathrm{KBC}$, there was no difference in the modulus values measured at 24 hours and 3 months.

Results of the modulus of resilience measurements are shown in Table 4. The modulus of resilience was greater in resin-modified glass-ionomers than in conventional acid-base products. The values for FIIR and FLR increased significantly after 3 months of water storage while the other products showed no statistically significant change between 24 hours and 3 months.

Fig. 1 shows the light microscopic view of the surface for FIIC (A) and FIIR (B) after being subjected to 20,000 cycles of steel balls loading. The surface of FIIR remained relatively smooth with no remarkable defects, while FIIC exhibited a concave surface caused by material loss, resulting in a rougher surface texture than that of FIIR. SEM views of the surface after loading are shown in Fig. 2. Compared with FIIR (B), the marginal breakdown of FIIC (A) was pronounced, and in a higher-magnification view (Fig. 3) gap formation was apparent around the margin. Marginal breakdown occurred at the edge of the cement material, exposing glass particles.

Table 3 Flexural modulus (GPa), mean (S.D.)

\begin{tabular}{|c|c|c|c|}
\hline & $30 \mathrm{~min}$ & $24 \mathrm{~h}$ & $3 \mathrm{~m}$ \\
\hline FIIR & $2.6(0.4)$ & $5.8(0.4)$ & $10.7(1.0) \mathrm{B}$ \\
\hline FIIC & $4.7(1.2) \mathrm{B}$ & $9.5(0.9)$ & $23.6(3.1)$ \\
\hline PFR & $5.0(1.3) \mathrm{B}$ & $7.6(1.2)$ & $7.2(0.7) \mathrm{A}$ \\
\hline $\mathrm{KFC}$ & $8.0(1.2)$ & $14.3(0.6)$ & $18.1(2.4)$ \\
\hline FLR & $0.7(0.1) \mathrm{A}$ & $2.0(0.2) \mathrm{A}$ & $6.2(0.4) \mathrm{A}$ \\
\hline FLC & $0.4(0.1) \mathrm{A}$ & $2.4(0.5) \mathrm{A}$ & $10.2(2.1) \mathrm{B}$ \\
\hline PBR & $1.3(0.1) \mathrm{A}$ & $3.3(0.4)$ & $3.1(0.4)$ \\
\hline $\mathrm{KBC}$ & $14.7(1.4)$ & $20.8 \quad(2.2)$ & $20.3(1.5)$ \\
\hline
\end{tabular}

For key see table 2 . 
Table 4 Modulus of resilience $\left(\mathrm{MJ} / \mathrm{m}^{3} \times 10^{-2}\right)$, mean (S.D.)

\begin{tabular}{|c|c|c|c|c|}
\hline & & $\min$ & $24 \mathrm{~h}$ & $3 \mathrm{~m}$ \\
\hline FIIR & 3.7 & (1.5) C & $4.8(1.6) \mathrm{B}$ & $8.5(2.1)$ \\
\hline FIIC & 0.8 & $(0.4) \mathrm{A}$ & $0.5(0.2) \mathrm{A}$ & $2.3(1.1) \mathrm{B}$ \\
\hline PFR & 1.1 & $(0.3) \mathrm{A}$ & $11.2(2.8)$ & $10.9(2.4) \mathrm{C}$ \\
\hline $\mathrm{KFC}$ & 1.3 & $(0.2) \mathrm{A}$ & $1.5(0.3) \mathrm{A}$ & $1.6(0.9) \mathrm{AB}$ \\
\hline FLR & 1.9 & $(0.7) \mathrm{AB}$ & $5.0(1.9) \mathrm{B}$ & $11.2(3.5) \mathrm{C}$ \\
\hline FLC & 1.4 & $(0.8) \mathrm{AB}$ & $0.3(0.1) \mathrm{A}$ & $0.6(0.6) \mathrm{A}$ \\
\hline PBR & 3.9 & $(0.8) \mathrm{C}$ & $5.5(1.0) \mathrm{B}$ & $6.6(2.4)$ \\
\hline $\mathrm{KBC}$ & 2.4 & $(0.3) \mathrm{BC}$ & $3.1(0.9) \mathrm{A}$ & $2.9(0.7) \mathrm{AB}$ \\
\hline
\end{tabular}

For key see table 2.

\section{DISCUSSION}

Glass-ionomers have been used clinically for 20 years. However, they are often not the first choice as restorative materials, even in low-stress regions, because of their relatively poor esthetics, sensitivity to moisture contamination during setting, and inherent brittleness. To overcome the problem of moisture sensitivity, a photo-curable resin component has been incorporated within some newer materials. Consequently these products have similarities to both glass-ionomer and resin matrix composite materials. In these resin-modified glassinomers there are at least two distinct setting reactions : an acid-base reaction as would be observed for a conventional glass-ionomer, and a light-initiated cross-linking of methacrylate groups similar to the setting reaction of resin composites ${ }^{2,13)}$. The basic composition of FIIR and FLR is fluoroaluminosilicate-glass powder, combined with a liquid which is an aqueous solution of a copolymer of acrylic acid and maleic acid, HEMA (2-Hydroxyethylmethacrylate), $\mathrm{H}_{2} \mathrm{O}$, camphorquinone, and activator. The setting reaction is described by the manufacturer as a normal glass-ionomer cement acid-base reaction followed by a polymerization of HEMA forming poly-HEMA initiated by exposure to visible light ${ }^{14)}$. For the PFR and PBR, the powder component contains a radiopaque sodium lanthanum calcium aluminum fluorosilicate glass, a copolymer of acrylic and maleic acid in dry form, and an activator necessary for light-curing. The liquid component contains a mixture of "glassionomer compatible monomers and oligomers", thought to be polyacid chains with pendant methacrylate groups, camphorquinone and $\mathrm{H}_{2} \mathrm{O}$. Setting is described by the manufacturer as being a combination of conventional cement setting combined with resin cross-linking to form a three-dimensional resin matrix. In these resin-modified glass-ionomers the resin cross-linking process can be controlled by the clinician as light activation results in a rapid initial set ${ }^{15}$, consequently early sensitivity to moisture during setting can be avoided. 


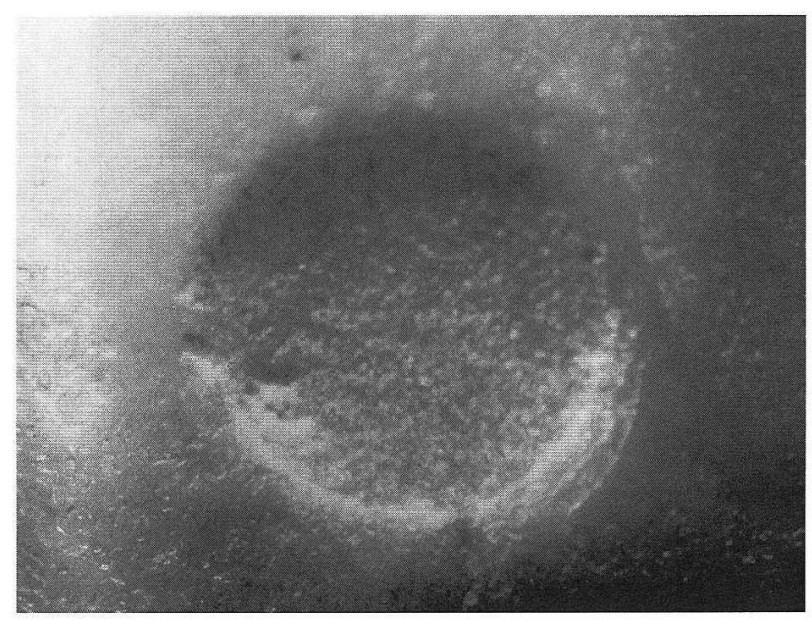

(A)

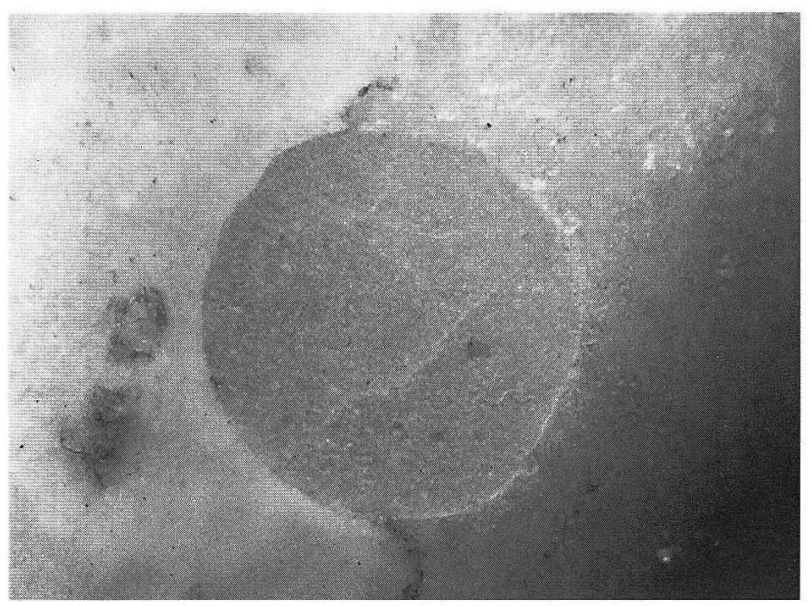

(B)

Fig. 1 Light microscopic view of FIIC (A) and FIIR (B) restored in a bovine labial cavity after being subjected to 20,000 cycles of steel balls loading. Original magnification : $15 \times$

Further benefits of using resin modified materials have been demonstrated in this study. The inherent brittleness of the conventional products has been overcome to some extent by incorporating a resin component into the matrix forming component of the cement. Modified glass-ionomers have a lower flexural modulus and are more plastic than conventional glass-ionomers. This may or may not be viewed as an advantage. However, the lower flexural modulus coupled with greater flexural strength resulted in greater values of resilience. In conventional glass-ionomers, the hydrated silica network-formation domi- 


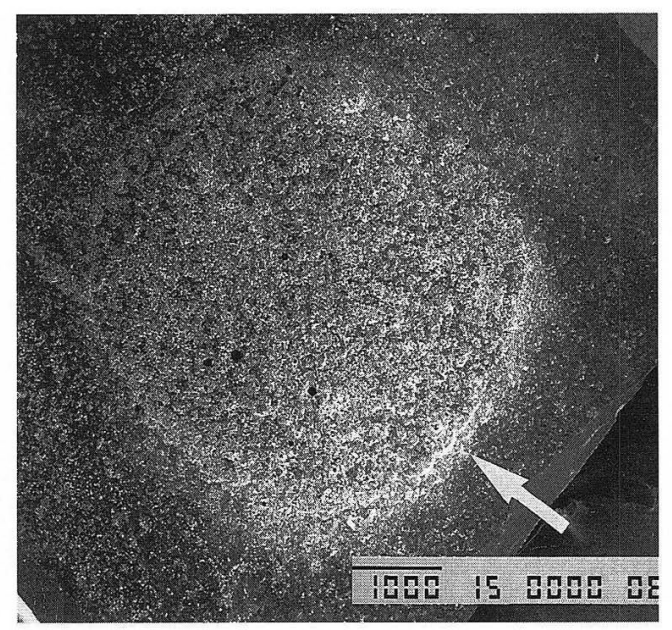

(A)

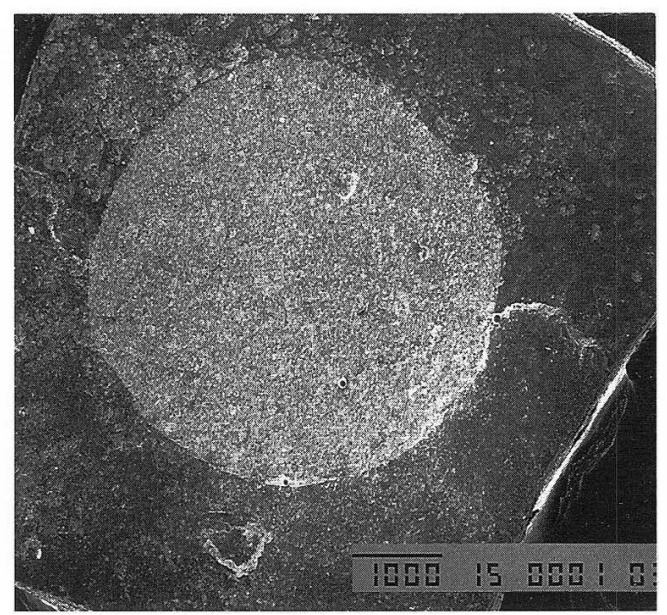

(B)

Fig. 2 SEM view of FIIC (A) and FIIR (B) of the same condition in Fig. 1. White arrow indicates the region where the marginal breakdown is apparent. Original magnification : $15 \times$

nates the matrix, making it susceptible to brittle failure. As shown in our results, after 3 months of aging conventional materials lost viscoelastic properties and increased considerably in flexural modulus, which might decline in stress relaxation. Burgess et al. ${ }^{16)}$ explained the matrix of a resin-modified glass-ionomer as it polymerizes through HEMA and methacrylate groups grafted onto polyacrylic acid, with the glass ionomer and resin matrices chemically linked. Tosaki and Hirota ${ }^{14)}$ also suggested that poly-HEMA and polyacrylate 


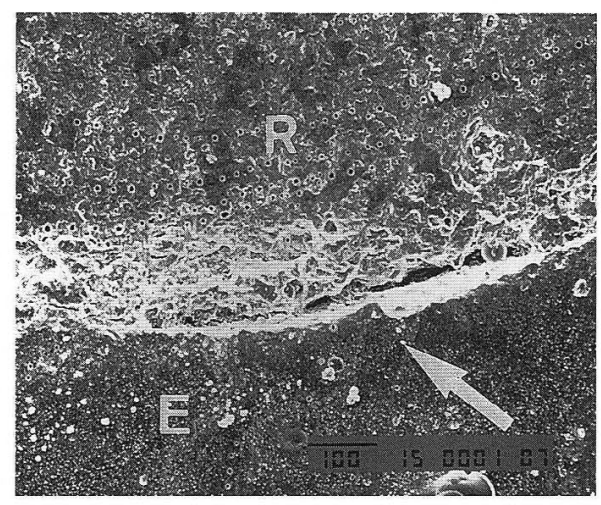

Fig. 3 Higher-magnification view of the area indicated by the white arrow in Fig. 2 (A). Original magnification: $80 \times(\mathrm{R}$ : Cement, $\mathrm{E}$ : enamel)

salts ultimately form a homogeneous matrix. Thus, the cross-linking photo-curable resin component incorporated in the cement matrix is believed to render the lower flexural modulus coupled with greater flexural strength, leading to greater values of resilience. In addition, the formation of the silica structure in resin-modified glass-ionomers is unlikely to occur to the same extent as in conventional glass-ionomers, since its formation would be hindered by the "snap-set" of the photo-curable resin matrix. The hydrated silicate structure was revealed to be responsible for a significant hardening of the material ${ }^{17)}$. This may explain the greater modulus of resilience shown in resin-modified glass-ionomers in which the matrix network was not as brittle as the normal cement matrix. After 20,000 cycles of steel ball loading, less marginal breakdown and less surface deterioration were found in a resin-modified restorative product (FIIR) than in a conventional acid-base product (FIIC). Greater flexural strength and modulus of resilience after one week of placement of a resinmodified glass-ionomer might render the restoration more resistant to material deformation and chipping. Wilson and Nicholson ${ }^{18)}$ stated that flexural strength and fracture toughness are clinically very important in evaluating the physical properties of glass-ionomers. In their work on fractography, Douglas and Lin $^{19}$ found significantly lower fracture toughness in conventional glass-ionomers than in resin-modified analogues, and confirmed the increased strength of the resin-modified materials. Regarding the modulus of resilience, Peutzfeldt and Asmussen ${ }^{20)}$ reported significant coefficients of correlation between modulus of resilience and quantitative clinical wear data for resin composite materials and implied that the resilience of a material influences its abrasion resistance in stress-bearing sites. These considerations might support the results of less marginal breakdown and surface deterioration found in a resin-modified glass-ionomer restorative than a conventional acidbase analogue after the cyclic loading test.

Unlike some other dental cements, the strength of conventional glass-ionomers increases over a period of storage. Wasson and Nicholson ${ }^{17)}$ proposed that this was caused by the 
formation of a silica matrix. Matsuya $e t a l .^{21)}$ confirmed this experimentally and suggested that the silica network structure was further developed after initial setting, leading to an increase in cement strength. In this study some resin-modified glass-ionomers showed a marked increase in strength over time, which suggests that setting by acid-base complexation continues long after the polymerization stage of the reaction is completed. Tosaki and Hirota $^{14)}$ explained that in FIIR and FLR the acid-base reaction continues after the cement has been polymerized by light irradiation and that poly-HEMA and polyacrylic metal salts form a homogeneous matrix which surrounds the glass particles. In these two materials flexural modulus significantly increased with the duration of water storage, and the rubbery characteristics observed in the early stages of setting disappeared as the cements matured. This characteristic was not observed in PFR or PBR. The change in flexural properties over time might reflect the extent to which cement setting by an acid-base reaction can occur after the initial polymerization stage. The acid-base reaction serves to further harden and strengthen the polymerized resin matrix ${ }^{13)}$. Our findings support the work of Burgess et al. ${ }^{16)}$, who reported that FIIR undergoes a cement setting more readily than PFR in the absence of activating light.

\section{CONCLUSION}

Flexural strength, flexural modulus, and modulus of resilience of 4 resin-modified "hybrid" glass-ionomers were tested and compared with 4 conventional acid-base glass-ionomers. For the resin-modified and conventional type restoratives marginal breakdown was also observed using a microscope and SEM after being subjected to cyclic loading. It can be concluded that resin-modified glass-inomers are stronger and more resilient than their conventional cement-setting counterparts. Improved properties supported the results obtained in the cyclic loading test, where less marginal breakdown and surface deterioration were seen in a resin-modified glass-ionomer than in a conventional analogue. Maturation of mechanical properties during storage depends on the capacity of the cement setting reaction to continue after initial polymerization.

\section{REFERENCES}

1) Mathis, R. S. and Ferracane, J. L. : Properties of a glass-ionomer/resin-composite hybrid material, Dent Mater 5 : 355-358, 1989.

2) Mitra, S. B., Li, M. Y. and Culler, S. R.: Setting reaction of Vitrabond ${ }^{\mathrm{TM}}$ light cure glass ionomer liner/base, Setting Mechanism of Dental Materials, Editor: Watts, D. C., Loch Lomond, Scotland, 1992.

3) Rusz, J. E., Antonucci, M., Eichmiller, F. and Anderson, M. H.: Adhesive properties of modified glassionomer cements, Dent Mater 8: 31-36, 1992.

4) Momoi, Y. and McCabe, J. F.: Fluoride release from light-activated glass ionomer restorative cements, Dent Mater 9 : 151-154, 1993.

5) Nicholson, J. W., Anstice,. M. and McLean, J. W.: A preliminary report on the effect of storage in water on the properties of commercial light-cured glass ionomer cements, $B r$ Dent $J$ 173: 98-101, 1992.

6) Anstice, H. M., Nicholson, J. W. and McCabe, J. F.: The effect of using layered specimens for determination of the compressive strength of glass-ionomer cements, J Dent Res 71 : 1871-1874, 1992. 
7) McCabe, J. F., Watts, D. C, Wilson, H. J. and Worthington, H. V. : An investigation of test-house variability in the mechanical testing of dental materials and the statistical treatment of results, $J$ Dent 18 : 90-97, 1990.

8) Sidhu, S. K. and Watson, T. F. : Resin-modified glass ionomer materials -A status report for the American Journal of Dentistry, Am J Dent 8: 59-67, 1995.

9) Burgess, J. O., Barghi, N., Chan, D. C. N. and Hummert T. : A comparative study of three glass ionomer base materials, Am J Dent 6: 137-141, 1993.

10) Huget, E. F. and Murray, G. A. : Strength, stiffness, resilience and toughness of restorative cements, $J$ Dent Res 73 : 219 (Abstr 940), 1994.

11) Momoi, Y., Hirosaki, K., Nishino, T. and Kohno, A.: Flexural properties of light-activated glass ionomer cements, J Dent Res 73 : 219 (Abstr 941), 1994.

12) Ibaraki, Y. : In vitro observation method of developmental changes of restorative materials (Part 2), Japan $J$ Conserv Dent 29 : 596-609, 1986. (In Japanese)

13) Wilson, A. D. : Resin-modified glass-ionomer cements, Int J Prosthodont 3 : 425-429, 1990.

14) Tosaki, S. and Hirota, K.: Current and future trends for light cured systems, Glass Ionomers : The next generation, Proceedings of the 2nd International Symposium on Glass Ionomers, Editor: Hunt, P. R., Philadelphia, PA, 1994 : pp. 35-46.

15) Bourke, A. M., Walls, A. W. and McCabe, J. F.: Light-activated glass polyalkenoate (ionomer) cements. The setting reaction, J Dent 20 : 115-120, 1992.

16) Burgess, J., Norling, B. and Smmitt, J. : Resin ionomer restorative materials -The new generation, Glass Ionomers : The next generation, Proceedings of the 2nd International Symposium on Glass Ionomers, Editor: Hunt, P. R., Philadelphia, PA, 1994, pp. 75-86.

17) Wasson, E. A. and Nicholson, J. W. : New aspects of the setting of glass-ionomer cements, $J$ Dent Res 72: 481-483, 1993.

18) Wilson, A. D. and Nicholson, J. W. : Acid-base cements, Their biomedical and industrial applications, 1st ed., The Press Syndicate of the University of Cambridge, Cambridge, 1993, pp. 116-175.

19) Douglas, W. H. and Lin, C. P.: Strength of the new systems, Glass Ionomers : The next generation, Proceedings of the 2nd International Symposium on Glass Ionomers, Editor: Hunt, P. R., Philadelphia, PA, 1994, pp. 209-216.

20) Peutzfeldt, A. and Asmussen, E. : Modulus of resilience as predictor for clinical wear of restorative resins, Dent Mater 8: 146-148, 1992.

21) Matsuya, S., Maeda, T. and Ohta, M. : IR and NMR analyses of setting for glass-ionomer cement, $J$ Dent Res 73 410: (Abst 2467), 1994. 


\title{
本号掲載論文の和文抄録
}

\author{
光硬化型グラスアイオノマーセメントの曲げ \\ 特性について従来型セメントとの比較 \\ 桃井保子，広崎国継 \\ 河野 篤, J. F. McCabe ${ }^{1}$ \\ 鶴見大学歯学部第一歯科保存学教公
}

${ }^{1}$ Dental Materials Science Unit, The Dental School, University of Newcastle upon Tyne, UK

\begin{abstract}
光硬化型と従来型グラスアイオノマーセメント（修復 用 2 種，裏層用 2 種）の曲げ強さ，弾性率，弾性ひずみ エネルギーを比較検討した，また，窩洞に充填した光硬 化型と従来型修復用セメントに, 多数の金属小球を繰り 返しぶつけ，裔洞辺縁と材料表面の劣化を光䫓および電 顕で観察した. 光硬化型は従来型に比べて, 曲け強さが 大きく，弾性率が低く，弾性ひずみエネルギーが大きい 事がわかった．また，光硬化型では辺縁や表面の劣化が

少ない事が観察できた。これらの結果から，グラスアイ オノマーセメントに光重合レジン成分が渿加されたこと で，グラスアイオノマーセメントの脆性が隇じ，材料が 永久変形をおこさずにより大きなエネルギーを吸収しう るようになった事が示された。. 3 力月間の水中浸漬で, 弾性率が有意に増す材料は, 変化しない材料に比べて, セメント中に占める酸一塩基反応の割合か゚大きく，長期 にわたってセメント反応が持続する事を示唆していた.
\end{abstract}

\section{臼歯用可視光線重合型コンポジットレジンの 10 年間の縦断臨床成績}

清水建彦，北野忠則，井上正義，成川公一

藤井弁次

大阪歯科大学歯科保存学講座

臼歯用可視光線重合型コンポジットレジン (LITEFIL P: Base resin: UDMA, Filler : micro crashed type, alumino-silicate, barium glass \& silica, 85 wt\%, 74 vol\%, Shofu Co., Kyoto, Japan) で修復し た 91 症例をUSPHS を改良した評価基準にしたがっ て, 10 年間毎年評価した. LITE-FIL P 修復した 91 症例は 10 年後 68 症例に減少した。 23 症例の喪失は修 復直後の歯䯣反応を示した 1 症例，第 3 大臼歯の挺出や
歯周疾患による抜歯が 4 症例，燐在歯の消失による支台 歯が 2 症例, 二次融蝕が 8 症例, レジン修復と全く関係 のない歯面の蔝蝕による䚻失症例は 8 症例であった，磨 耗は比較的少なく, 辺縁適合性も良好で, 変色もないこ となどから，全ての評価項目を総括すると，比較的小範 囲の修復に限ればLITE-FIL P の 10 年間の臨床成績は 概ね良好であり， 臼歯部修復材として十分応用価値があ ることが認められた。

陶歯と種々の歯科用合金に対する混合シラン処理剤の効果

楳本貢三，倉田茂昭 ${ }^{1}$

神奈川歯科大学歯科理工学教室

1神奈川歯科大学歯科生体工学教室 